\title{
Yaşlanmayla birlikte ağız ve çevresindeki dokularda gözlenen yapısal ve fonksiyonel değişiklikler
}

\author{
Esin Bozdemir(0000-0002-2421-3807) ${ }^{\alpha}$, Hakan Amasya(0000-0001-7400-9938) ${ }^{\alpha}$
}

Selcuk Dent J, 2019; 6: 239-246 (Doi: 10.15311/selcukdentj.439068)

Başvuru Tarihi: 29 Haziran 2018 Yayına Kabul Tarihi: 26 Kasim 2018

\begin{abstract}
ÖZ
Yaşlanmayla birlikte ağız ve çevresindeki dokularda gözlenen yapısal ve fonksiyonel değişiklikler

Yaşlanmanın organizma üzerindeki majör etkileri arasında, ağız boşluğunda ve dolayısıyla onu çevreleyen dokularda meydana gelen değişiklikler önemli bir yer tutar. Fizyolojik değişimlerin yanı sıra, ileri yaş dönemine özgü ağız, diş ve dişeti hastalıkları da izlenmektedir. Yaşlanmayla oluşan değişikliklerle hastalık durumunda görülen değişiklikler arasındaki fark her zaman net olmadığından bu iki durum arasındaki sınıı belirlemek çoğu zaman mümkün değildir. Bu nedenle yaşlanma süreci nedeniyle doku ve organlarda ortaya çıkan değişiklerin ilgili doku ve organlardaki hastalıkların doğru tanısı ve tedavisi için bilinmesi önemlidir. Yaşlanmayla birlikte dişlerde; dentin tubüllerinin daralması, sekonder dentin kalınlığında artma, sementin kalınlaşması, oral mukozada; atrofik değişikliklerle pürüzsüzleşmesi, elastikiyetin ve portakal kabuğu görünümünün kaybolması gibi yapısal değișikliklerle ve dil mobilitesi ile dudak kapanışındaki azalma, çiğneme kaslarının tonusunun azalması gibi nedenlerle lokmanın hazırlanmasının zorlaşması, dilde tat reseptörlerinin azalması sonucu tat almada azalma gibi çeşitli fonksiyonel değişiklikler ortaya çıkmaktadır. Bu derlemenin amacı yaşlanma süreciyle birlikte dişler, periodonsiyum, dişleri çevreleyen kemik, ağız mukozası, çiğneme kasları, tükürük bezleri ve çene ekleminde meydana gelen yapısal fonksiyonel değişikliklerle ilgili bilgi vermektir.
\end{abstract}

\section{ANAHTAR KELIMELER}

Dişler, oral mukoza, tükürük bezleri, yaşlanma

\section{ABSTRACT}

The structural and functional changes observed in mouth and surrounding tissues with aging

The changes in oral cavity and its surrounding tissues play an important role among the other major effects of aging. In addition to physiological changes, oral, dental and gingival diseases specific to advanced age are also observed. Since the difference between disease and age-related changes is not always clear, it is often not possible to determine the boundary between these two conditions. Therefore, it is important that the changes occurred in tissues and organs in the aging process are known for the correct diagnosis and treatment of diseases in the tissues and organs. Structural changes such as contraction of dentin tubules, increase in secondary dentin thickness, thickening of cementum in the teeth; smoothing with atrophic changes, loss of elasticity and appearance of orange peel in oral mucosa and functional changes such as difficulty in preparing of the morsel due to decreased lip closure and tongue mobility, the reduction of tonus of chewing muscles, reduction in taste due to decrease in taste receptors on the tongue occurred in the ageing process. Purpose of this review is to give information about structural and functional changes can be seen in teeth, periodontium, surrounding bone, oral mucosa, masticatory muscles, salivary glands and temporomandibular joint by aging.

\section{KEYWORDS}

Teeth, oral mucosa, salivary glands, aging

değişiklikler; organ kütlesindeki azalma; ve vücut sisteminin fonksiyonel rezervlerinin azalması ve kaybı şeklinde 3 tip fizyolojik değişiklik görülür. ${ }^{2}$ Yaşlanmanın insan organizması üzerindeki etkisi bütün organ ve dokularda izlenebilir. ${ }^{3}$ Ağız mukozası, çene kemikleri, dişler, dişleri destekleyen dişeti, periodonsiyum gibi yapılarda, çiğneme kaslarında, tükürük bezlerinde ve çene ekleminde de belirgin değişiklikler meydana gelir. ${ }^{4}$

Yaşlanmayla oluşan değişikliklerle hastalık durumunda görülen değişiklikler arasındaki fark her zaman net olmadığından bu iki durum arasındaki sınırı belirlemek çoğu zaman mümkün değildir. Bu nedenle yaşlanma süreci nedeniyle doku ve organlarda ortaya çıkan değişiklerin ilgili doku ve

\footnotetext{
${ }^{\alpha}$ Süleyman Demirel Üniversitesi, Diş Hekimliği Fakültesi, Ağız, Diş Ve Çene Radyolojisi Anabilim Dalı, Isparta
} 
organlardaki hastalıkların doğru tanısı ve tedavisi için

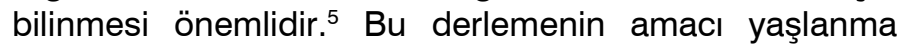
süreciyle dişler, periodonsiyum, dişleri çevreleyen kemik, ağız mukozası, çiğneme kasları, tükürük bezleri ve çene ekleminde meydana gelen yapısal ve fonksiyonel değişikliklerle ilgili bilgi vermektir.

\section{Dişler}

Dişler mine, dentin, sement ve pulpa dokularından oluşan vücuttaki en sert yapılardır. Diş gelişiminin tamamlanmasından sonra dişte gerçekleşen tüm değişiklikler yaşlanmanın etkileri olarak değerlendirilir. Dişler kısıtlı tamir ve rejeneratif kapasitesi sebebiyle vücudun diğer yapılarından farklıdır. Dokuların çoğunda fizyolojik turn-over görülürken minede görülmez. Yaşla birlikte dişin formunda makroskopik değişiklikler gerçekleşir. Perikimata ve imbrikasyon çizgilerinin kaybolmasıyla diş yüzeyindeki detaylar kaybolarak daha düzgün bir görünüm oluşur. Aşınma ve atrizyon diş formunu etkiler. Atrizyon sonucu dişlerin anatomik kron boyu kısalır ve minenin altında yer alan dentin dokusu açığa çıkabilir. Dişlerin aproksimal yüzeylerinde oluşan aşınmalar sonucunda dental ark boyutunda azalma gerçekleşir. Yaş ile birlikte diş minesinin hem ışık, hem madde geçirgenliği azalıp kırılganlığı artar. Yaşam boyu devam eden oral çevre ve mine arasında meydana gelen iyon değişimini yansıtacak şekilde yaş arttıkça mine daha az geçirgen hale gelir. Yaşlılarda mine renginde koyulaşma ve renklenmeler mevcuttur. Bunun nedeni organik materyalin absorbsiyonu olabilir. Minedeki nitrojen oranı yaşla birlikte artmaktadır. ${ }^{6-8}$

Yaşlanmaya bağlı olarak dentinde fizyolojik sekonder dentin oluşumu ve dentin tübüllerinin zamanla tıkanmasıyla oluşan dentin sklerozu şeklinde iki tip yapısal değişiklik meydana gelir. Dentin tübüllerinin çoğunluğu tamamen minerallerle doludur. Koronal dentindeki tübül çapı genç bireylerde (16-32 yaş aralığında) 4-9 $\mu \mathrm{m}$ arasında değişirken yaşlı bireylerde (50-75 yaş aralığında) 2-9 $\mu \mathrm{m}$ arasında değişmektedir. ${ }^{9}$

Dentin-pulpa sınırında bulunan odontoblast adı verilen özelleşmiş bağ dokusu hücreleri yaşam boyunca sekonder dentin sentezlemeye devam ederler. Dentin kalınlığı her gün yaklaşık 0,5 $\mu \mathrm{m}$ artarken kalınlıktaki artış miktarı yaşam boyu azalır. Sürekli dentin yapımı, pulpa odası ve kanallarında daralmaya yol açar.6,7,10-12 Dentindeki kalitatif ve kantitatif (kalınlık) değişiklikler dentinin ışık geçirgenliğini azaltır. Bununla birlikte anatomik defektlerin pigmentasyonu, korozyon ürünleri ve yetersiz ağız hijyeni de diş rengini değiştirebilir. ${ }^{6}$ Atrizyon sonucu madde kaybının hangi aşamada patolojik kabul edileceği hakkında fikir birliği yoktur. Dişeti seviyesine kadar ulaşan diş sert dokularındaki kayıpların uyarımı sonucu pulpa tavanında oluşan tamir dentini, yaşlı insanlarda ağrı hassasiyetindeki azalmayı açıklayabilir. Ayrıca dentin tubüllerinin daralması ve sekonder dentin kalınlığındaki artmanın pulpa reaksiyonlarını engellemesi, dentin dokusundaki hassasiyeti azaltacağından yaşlılarda bazı dental işlemler yapılırken anesteziye ihtiyaç duyulmaz. ${ }^{11,13}$ Kalın sekonder dentin pulpa reaksiyonların engellediğinden dental işlemler sırasında açı̆̆a çıkan ısının pulpaya zarar verme intimali ve buna bağlı pulpitis gelişme insidansı yaşlılarda daha azdır. ${ }^{7}$ Kök dentininin sklerozu kökün daha kırılgan olmasına neden olduğundan çekim sırasında dişin kırılma riski artmaktadır. ${ }^{7}$

Sement kalsifiye olmuş mezenşimal bir dokudur ve diş köklerinin en dış tabakasını oluşturur. Rezorbe olabilen bir dokudur ve bu özelliği yaşla artar. Yaşlanmayla beraber sementte oluşan en büyük değişiklik kalınlaşmadır. Sementte matriks depozisyonu ve kalsifikasyonu, sekonder dentin yapımı gibi hayat boyu devam eder. ${ }^{11}$ Yaşla birlikte dişler, çiğneme sonucu aşınan diş sert dokularını telafi etmek için destek yapıları sayesinde sürmeye devam ederler. ${ }^{14}$ Yaşla birlikte kökün özellikle apikal yarısında sement yapımına devam edilerek atrizyon, periodontal hastalıklar veya travma gibi sebeplerle kaybedilen yükseklik telafi edilir. Sement birikimi ömür boyu devam etse de formasyon oranı yaşla azalır. Bazı durumlarda aşırı sement birikimi (hipersementoz), kontağını yitirmiş bir dişin uzaması veya enflamatuar bir uyaran ile ilişkili olabilir. Yaşla birlikte sementin flor ve magnezyum içeriğinde artma görülür. 6,7

Pulpa gevşek bağ dokusu elemanlarından oluşur. Yaşla birlikte pulpada kollajen lif sayısı artarken pulpanın hacmi ve hücre sayısı (odontoblastlar, fibroblastlar ve mezenşimal hücreler) azalır. Dişlerin altındaki bölgelerde kapiller damarlardan gelen kan akımı oldukça azalır. Bu değişiklikler pulpanın tamir kapasitesini düşürmesi nedeniyle önemlidir. ${ }^{6-8,11}$ 1992 yılında yapılan bir çalışmada elektron mikroskop incelemesinde yaşla birlikte pulpa dokusunda hem miyelinli hem miyelinsiz sinirlerde kayıp ve dejenerasyon olduğu ve bu durumun pulpanın iyileşme kapasitesini etkilediği bildirilmiştir. ${ }^{15}$

Nöronların azalması sebebiyle vitalite testlerine cevap alınması zorlaşabilir. Pulpa kalsifikasyonlarının görülme insidansı, sayısı ve boyutu artar. Yaşla birlikte diffüz kalsifikasyonlar ve kök kanallarında daralma gözlenir. Pulpada yaşlanmayla artan fibrozis sonucu pulpa dokusu tamamen fibröz doku ile yer değiştirir.6,7,10-12

Yaşla birlikte dişlerde görülen değişiklikler ${ }^{8}$ Tablo 1'de gösterilmektedir. 
Tablo 1.

Yaşla birlikte diş yapılarında gözlenen değişiklikler ${ }^{8}$

\begin{tabular}{|ll}
\hline Mine & \\
\hline Rejenerasyon kapasitesi/tamir & Yapılamaz \\
\hline Geçirgenlik & Azalır \\
\hline Dentin & \\
\hline Geçirgenlik & Azalır \\
\hline Hassasiyet & Azalır \\
\hline Kalsifikasyon & Artar \\
\hline Ağrı iletimi & Azalır \\
\hline Tamir & Canlı pulpa varsa mümkündür \\
\hline Pulpa dokusu ve kanalı & \\
\hline Pulpanın hacmi ve hücre sayısı & Azalır \\
\hline Nöron sayısı & Azalır \\
\hline Diş drenajı & Azalır \\
\hline Damarlanma & Azalır \\
\hline Apikal foramen & \\
\hline Boyut & Azalır \\
\hline Sement & \\
\hline Depozisyon & Azrtar \\
\hline Tamir & Artar \\
\hline Rezorbsiyon & Azalır \\
\hline Dişin bütünü & Canlı pulpa varsa mümkündür \\
\hline Kırılganlık & Yatkınlık artar \\
\hline Renkte koyulaşma & \\
\hline Ağrı hassasiyeti & \\
\hline Işık geçirgenliği & \\
\hline
\end{tabular}

\section{Periodonsiyum}

Dişeti, sement, alveoler kemik ve periodontal ligament gibi dişi destekleyen yapılardan oluşan fonksiyonel ünite periodonsiyum adını alır. Yapısında epitelyum dokusu ile mineralize olmuş ve mineralize olmamış bağ dokusu bulunur. ${ }^{11}$ Yaş ile periodontal hastalık arasında ilişki bulunamasa da yaşlı bireylerde periodontal hastalık görülme olasılığı daha yüksektir. ${ }^{7}$

Insanlarda ve deney hayvanlarında yapılan çalışmalarda yaşlanmaya bağlı olarak dişeti epitelinde bir değişiklik olmadığı tespit edilmiştir. Yaşın artmasıyla periodontal ligamentte hücre yoğunluğunda azalma ve rete peglerin düzleşmesi gözlenir. ${ }^{11,16}$

Yaşlanma dişeti bağ dokusunun daha sıkı ve düzensiz bir yapıya dönüşmesine yol açar. Bağ dokusundaki kısa, yoğun ligamentlerin yaşlanması sonucu yumuşak dokuda ataşman kaybı, dişlerde mobilite gözlenebilir. Kollajende kantitatif ve kalitatif değişiklikler rapor edilmiştir. Periodontal ligament yaşlanmayla daha düzensiz bir yapı haline gelir ve fibroblastlar sayıca azalır. Ayrıca elastik liflerin sayısı artar ve organik matriks yapımı azalır. Yaşlanmayla birlikte periodontal ligamentteki mitotik aktivitede azalma nedeniyle periodontal ligament hücre tamir kapasitesi azalır. Alveoler kemik ve periodontal ligamentte damarlarda arteriyoskleroz gelișir. $8,11,12$

\section{Kemik}

Kemik dokusu devamlı değişim içinde olan dinamik bir dokudur. Yaşlanmaya bağlı alveoler kemikte görülen değişiklikler, vücudun diğer kemiklerinde görülen değişikliklere benzer. Yaşlılarda kemiklerde rezorbsiyon, apozisyona kıyasla artmıştır. ${ }^{4,11}$ Yaş ile birlikte aktif periodontal hastalık bulguları ve diş kaybı olmadan da kemik kaybı kaçınılmaz olsa da alveol kemik atrofisinin birinci sebebi diş kaybıdır. 35-40 yaşlarından sonra her yıl her iki cinsiyet için toplam kemik kütlesinin yaklaşık \% 1'i kaybedilir. Alveolar kemik bu kütle kaybından en çok etkilenen kemiklerdendir. Farklı etiyolojik nedenler ve hastada bulunan bazı sistemik hastalıklar nedeniyle kemik kaybının miktarı değişebilir. ${ }^{7,8}$ Yaş ile ilişkili osteoporoz kemik kitlesindeki azalma için bir risk faktörü olmasına rağmen aralarındaki ilişki henüz net gösterilmemiştir. ${ }^{7}$

Yaşlıda hem maksilla hem de mandibulada kan akımı azalmıştır. $\mathrm{Bu}$ durum arteriyosklerotik değişikliklere veya diş kaybına bağlı olarak meydana gelebilir. Diş kaybı, çene kemiklerindeki rezorpsiyonu arttırmaktadır. Diş kaybı nedeniyle azalmış mekanik yük kemik yapısının kuvvetini, yoğunluğunu ve rijitliğini etkiler. ${ }^{3,14}$ Mandibulanın vertikal yönde, maksillanın yanak sebebiyle horizontal yönde rezorbsiyonu sonucu çene ve burun arasındaki mesafenin kısalması ve dudakların içeriye doğru çekilmesiyle karakteristik 'dişsiz görünüm' oluşur. ${ }^{7,8}$

Kemikteki kitle ve yoğunluk kaybı yaşlanma esnasında kasların gerginliği, koordinasyonu ve innervasyonundaki değişikliklerle ilişkilidir. Kemik, kas gibi mekanik sinyallere son derece hassastır. $\mathrm{Bu}$ nedenle çiğneme kuvvetinin yaş arttıkça azalması mandibular osteopeni etiyolojisine kuşkusuz katkıda bulunur. ${ }^{17}$

Mandibula, maksillaya oranla rezorbsiyondan 4 kat daha fazla etkilenir. Dişsiz mandibulada vertikal boyut azalır. Bu duruma bağı olarak, çeşitli fonksiyonlar sırasında perioral kasların kontrolü azalır. Bu yüzden koronoid çıkıntı küçülür, kondiler büyüme olur ve mandibula daha öne doğru yer değiştirir. Protez kullanmayan yaşı hastalarda bu durum, yüzde ve dudaklarda çöküntüye, ağızda büzülmeye ve dudak köşelerinden başlayan 
kırışıklıklara neden olur. Kretin küçülüp sivrileştiği durumlarda protez kullanımı zorlaşır. Mandibular rezorpsiyon sonucu mandibular kanal daha superior bir konum alır ve foramen mentale açığa çıkar. Bu durumda ağrı ve parestezi oluşabilir. Maksillada rezorpsiyon sonucu palatal kemik ve alveoler kret tamamen düzleşebilir. Maksiller sinüs ağız mukozasından sadece ince bir kemik tabakası ile ayrılır. Dişsiz hastalarda fonksiyonsuzluk atrofisi sonucu kalın trabeküllerde kayıp, kortikal incelme, alt ve üst çene hacminde genel bir azalma meydana gelir. ${ }^{3,8}$ Kemik onarımında önemli bir rol oynayan siklooksijenaz 2 (COX 2) enziminin seviyelerinin yaşlanma ile dramatik bir şekilde azalmaktadır. Bu durum yaşlı hastalarda ortaya çıkan gecikmiş kemik iyileşmesini

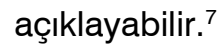

\section{Oral mukoza}

Oral mukoza, konakçının iyi olmasını ve genel sağlığını etkileyen temel koruyucu işlevleri yerine getirir. Ağız mukozasında bulunan epitel ve bağ dokusundan oluşan iki histolojik tabakanın önemli koruyucu fonksiyonları vardır. Birbirine bitişik, sıkı tutunmuş hücrelerden oluşan tabakalı yassı epitel fiziksel bir bariyer oluşturarak toksik maddelerin ve mikroorganizmaların girişini engeller. Yaşla birlikte tabakalı yassı epitel atrofiye olur, elastikiyetini kaybeder ve daha ince hale gelir. Ayrıca yaşlıda immunolojik yanıtın azalması enfeksiyon ve travmaya eğilimi daha da arttırır. ${ }^{6}$

Daha önceki çalışmalarda oral mukozanın yaşla birlikte atrofik değişikliklere uğrayıp pürüzsüzleştiği, elastikiyetin ve portakal kabuğu görünümünün kaybolmasıyla saten benzeri ödematöz bir görünüm kazandığı bildirilmiştir. Ayrıca yüzey epitelinde kuruma, vaskülarite kaybı, altındaki bağ dokuya ve kemiğe tutunmanın zayıflaması gibi durumlar da ortaya çıkar. Ağız kuruluğu, dilde, damakta veya oral mukozada ağrı veya yanma hissi gibi klinik semptomlar, bağ doku ve subkutan yağ dokuda azalma ve kollojen molekülleri arasındaki bağın kuvvetlenmesi gibi yaşlanmayla oluşan değişikliklerle ilişkilidir. ${ }^{6,8}$

Yaşla birlikte dilde makroglossi görülme olasılığı artar. Filiform papillalarda atrofi gözlenebilir ve dil pürüzsüz, düz bir görünüm kazanabilir. ${ }^{18}$ Dilde epitel tabaka incelirken progenitör hücre kalınlığı değişmese de bu hücrelerin aktivitesi azalır (progenitör - öncül hücreler; vücudun onarımında görev alan, erişkin dokuları yenileyebilme yetisine sahip hücrelerdir). Yaşla birlikte lingual varis gelişimi ve kandidal enfeksiyonlar gibi durumlara yatkınlık artarken yara iyileşmesinde gecikme görülür. Dilde kapiller damarlarda tıkanma ya da aterosklerozise daha az eğilim olduğundan diğer organlarla karşılaştıııldığında çok az damarsal değişiklik görülür. $6,8,19$
Desai ve ark. gülümseme sırasında aktif olan kasların yaşlanma ile birlikte güçsüzleşerek gülümsemenin dikey olarak azaldığını yatay olarak genişlediğini bildirmişlerdir. ${ }^{20}$ Penna ve ark. yaptıkları çalışmalarında yaş ile birlikte histomorfometrik analizde total dudak kalınlığında azalmayla birlikte orbicularis oris kasında önemli atrofinin olduğunu ve kutis kalınlığının yaşla azalırken yaşlı dudaklarda subkutan yağ dokusunun arttığını bulmuşlardır. Ayrıca vermilyon sınırını belirleyen orbikülaris oris kas açısında artış ve dermisteki elastik ve kollojen fibrillerde dejenerasyon gözlemlemişlerdir. ${ }^{21}$ Wohlert ve ark. dudağın vermilyon hattındaki tat duyusunun yaşla azaldığını ve bu azalmanın erkeklerde daha fazla olduğunu bildirmişlerdir. ${ }^{22}$ Bununla birlikte dudak dokusu kompozisyonunda ve reseptör yoğunluğundaki marjinal değişiklikler, yaşlılardaki his azalmasının nedenleri olabilir. ${ }^{19}$ Labial komissurada görülen kırışıklıkların primer sebebi dikey boyut kaybıdır. $^{5}$

\section{Çiğneme ve ağız çevresi kasları}

Yaşlı yetişkinde devam eden kas fonksiyonu; konuşma, çiğneme gibi oral fonksiyonların sürekliliği için büyük gereksinimdir. Yapılan çalışmalar parsiyel ya da tam protez kullanımının çiğneme etkinliği ve çiğneme kuvvetinin seviyesini etkilediğini göstermiştir. Kas kütlesinin yağ veya fibröz bağ dokusu ile yer değiştirmesi kaslarda atrofiye yol açar. İlerleyen yaşla çiğneme kaslarının X-ray densitesinde azalma, kaslardaki yağ ve fibröz dokunun artmasının göstergesi olarak yorumlanır. Çiğneme kaslarında gözlenen atrofi, çiğneme performansını düşürerek çiğnemeyi zorlaştırmaktadır. ${ }^{8,19,23}$

Yaşlanma ile birlikte vücuttaki diğer kaslara benzer şekilde çiğneme kaslarının kas tonusunda, performansında, kas hücrelerinin sayısı ve aktivitesi ile kas fibrillerinin sayısı ve boyutunda azalma gözlenir. ${ }^{8}$ Bunun sonucu olarak yumuşak gıdaların tercih edilmesi yaşlılarda dengesiz bir beslenmeye yol açabilir. ${ }^{7,24}$ Yiyeceğin yapısal özelliklerine bağlı olarak çiğneme sürecinde çiğneme siklusunun elektromiyografik aktivitesinin süresi ve genişliğinde değişikliklere neden olan motor adaptasyon oluşur. Yaşla birlikte kas liflerinin boyutundaki azalmadan ziyade sayılarındaki azalma toplam kas kitlesindeki azalmada daha etkilidir. Kasları innerve eden sinirlerde görülen dejenerasyon sebebiyle kaslarda güç kaybı ortaya çıkar. ${ }^{7}$

Yaşlanmayla kasların mekanik performansında ve vücudun çiğneme kaslarını da içeren tüm iskelet kas kitlesinde progresif bir azalma olduğu kanıtlanmıştır. Masseter kasın alanı ve ısırma kuvveti azalır. Çiğneme kaslarını (masseter, temporal kas) ve onların fonksiyonlarını elektromiyografik analiz kullanarak değerlendirmek ve yaşılıarı gençlerle karşılaştırmak 
amacıyla yapılan bir çalışmada, her iki grubun masseter kas aktivitelerinin karşılaştırılması sonucu istatistiksel olarak önemli farklılıklar bulunmuştur. Ayrıca kas kitlesindeki azalma kas kuvvetinde azalmaya yol açsa da yaşlılarda kasın elektromiyografik kontraksiyonu, genç kişilerle aynı ya da çok az düşük olarak bulunmuştur. Çiğneme kaslarında yaşın etkisiyle kas kitlesinde azalmanın yanında aponörotik yapıların gelişmesi, maksimum gerilmede önemli azalma, izometrik ve dinamik kas kuvvet kaybı ortaya çıkar. ${ }^{12,24}$

Yaş ile birlikte yutkunmada ciddi değişiklikler gözlenmese de, dil mobilitesi ve dudak kapanışındaki azalma, çiğneme kaslarının tonusunun azalmasıyla lokmanın hazırlanmasının zorlaşması sonucu yutkunma zorlaşabilir. 8,19

\section{Tükürük bezleri}

Tükürük, major (parotis, submandibular ve sublingual) ve minör (palatal, labial, ve bukkal mukozal yüzeylerde bulunan) tükürük bezleri sekresyonları, dökülmüş hücreler, plak, bakteri, yiyecek artıkları ve dişeti oluğu sıvısından oluşan mukozal sıvıdır. Tükürüğün ağız sağlığının devamlıı̆̆ının sağlanmasındaki fonksiyonları; mukozanın nemli ve kaygan tutulması, mikrobiyal ekolojik dengenin devamlılığının sağlanması, ağız boşluğunun mekanik olarak temizlenmesi, antibakteriyel ve antifungal aktivite, nötralizasyon-tamponlama, dişlerin remineralizasyonu, tat alma hassasiyetine ve sindirime katkı, üst hava yolunun, sindirim yolunun korunması olarak özetlenebilir. Tükürüğün olmamasının konak için yıkıcı sonuçları vardır. ${ }^{6,11}$

İlerleyen yaşla birlikte gerek majör gerekse minör tükürük bezlerinde çeşitli kantitatif ve kalitatif histolojik değişiklikler meydana gelir. Bu değişiklikler arasında asiner hücrelerde atrofi, duktal proliferasyon en sık görülenleridir. ${ }^{3,6}$ Yaşla birlikte asiner dokularda atrofi, duktal bileşenlerde proliferasyon ve tükürük bezlerinde dejeneratif değişiklikler ve fibroadipoz dokuda artış gözlenir. Bu değişiklikler yaş ile birlikte doğrusal bir şekilde ilerler. ${ }^{6}$

Geçmişte tükürük akışının yaşla azaldığı düşünülmekteydi. Yaşla birlikte tükürük bezlerininin salgısının durumu hakkında genel bir kanıya varmak zordur. Bugün için sistemik olarak sağlıklı ve ilaç kullanmayan yaşlılarda majör tükürük bezlerinden salınan sekresyonun hacminin ve kompozisyonunun yaşlanma sürecinden etkilenmediği düşünülmektedir. Bu görüş erişkin dönemde yaş artışına bağlı olarak majör tükürük bezlerinde \% 25-30 sıklığında asiner hücre kaybı oluştuğu gerçeğiyle ters düşmektedir. Çünkü sıvının büyük kısmı asiner dokuda üretildiğinden, sağlıklı yaşı bireylerde sekresyon hacminin değişmemesi şaşırtıcıdır. Bu durum tükürük bezlerinin fonksiyonel olarak farklı rezervuar kapasitelerine sahip olmalarına bağlı olabilir. Bugün, sağlıklı yaşlılarda, parotis bezinin sekresyon hızının değişmediği gösterilmiştir. Submandibular bezle ilgili sonuçlar ise çelişkilidir. Ancak minör tükürük bezi sekresyonlarının, artan yaşla birlikte azaldığı gösterilmiştir. ${ }^{6,11}$ Tükürük bezleri fonksiyonel kapasitelerini korumaktadır. Böylece bezler ömür boyu kesintisiz salgı yapabilmektedir. Yaşla birlikte parotis bezinin yağ ve fibröz dokularında artış gözlenir. ${ }^{6}$

Yaşlıda tükürük bezlerinde görülen morfolojik ve fonksiyonel değişiklikler, yaşlanmanın fizyolojik etkilerinden çok patolojik olaylara, kullanılan ilaçlara ve radyasyon tedavisine bağlı olarak gelişir. Yaşlıda görülen tükürük bezi hipofonksiyonlarının en önemli nedeni ilaç kullanımıdır.,8 Yaşla tükürüğün sadece miktarı değil, içeriği de değişir. Yaşla birlikte tükürük müsinöz bir özellik kazanır. Bu duruma bağlı olarak bakteriyel plak birikimi ve dolayısıyla çürük ve/veya periodontal hastalık riski artar. Yaşlılıkta tükürüğün iyonik kompozisyonunda da değişiklik oluşur. Yaşıların kullandığı ilaçlar elektrolit dengesindeki değişikliklere neden olduğu gibi tükürük kompozisyonunu da potansiyel olarak değiştirebilir. ${ }^{3,25}$ Yaşlılarda antikolinerjik yan etkisi olan ilaç kullanmadıkları müddetçe tükürük akışında önemli bir değişiklik olmadığı kabul edilmektedir. Bununla birlikte sağlıklı bir popülasyonda belirli bir tükürük bileşeninin (örneğin laktoferrin, sodyum, potasyum gibi) salgılanmasında yaşla ilişkili bir azalmanın olmadığı bildirilmiştir. İlginç bir şekilde düşük kalorili yiyecek tüketen herhangi bir ilaç kullanmayan yaşıların tükürük fonksiyonlarında yaşla ilişkili önemli değişlikler olduğu rapor edilmiştir. ${ }^{5,12}$

Tat alıcılarının fonksiyonunun korunması, kişinin ihtiyacı olan yiyecekleri seçmesinde önemlidir. Yaşlıların tat algısında \% 80'e varan oranda, özellikle tatlı, tuzlu, acı ve asitli maddelerle ilişkili bir azalma yaşandığı bildirilmiştir. Yaşlanmayla birlikte tat tomurcuklarında rapor edilen değişiklikler; tat tomurcuklarının sayısında azalma, epiteldeki tat tomurcuğu yoğunluğunda azalma ve bir tat tomurcuğundaki tat hücrelerinde azalmadır. ${ }^{26}$ Feng ve arkadaşları yaptıkları bir çalışmada insanlarda sirkumvallat papillalardaki tat tomurcuklarının sayının 74-85 yaş grubundaki kişilerde önemli ölçüde azaldığını bildirmişlerdir. ${ }^{27}$

Tat reseptörleri dildeki dört papilla tipinden üçünde (circumvallate, fungiform ve foliate) ve ayrıca damak epiteli, tonsiller sütun ve nazofarinks bölgesinde bulunurlar. Yaş ile tad almada değişiklik (disguzi), azalma (hipoguzi) veya kaybolma (aguzi) gözlenebilir. $\mathrm{Bu}$ değişikliklerde tükürük akışındaki azalma da etkilidir. Tat duyusunun uyarılması tükürük akışını 
hızlandııı ancak aşıı tuz ve baharat kullanımı sağlık sorunlarına yol açabilir. ${ }^{7,8,19}$ Bununla birlikte palatinal mukozanın hareketli protezlerle kaplı olması ile tat almada değişiklik olması arasındaki ilişki literatürde tartışmalıdır. Yapılan çalışmalarda protez materyaline bakılmaksızın damağı kaplayan protez varlığının tat duyusunu etkilemediği rapor edilmiştir. ${ }^{28-30}$ Çeşitli sistemik hastalıkların varlığı ve sigara alışkanlığı koku duyusunu yaşlanma sürecinden daha fazla etkiler. Çoğu araştırmacıya göre koku duyusu yaşlanma ile birlikte tat duyusuna göre daha fazla kaybolurken, koku duyusunun yaşlanma ile azaldığı kesin kanıtlanmamıştır. Yaşlı insanlar kokuları duymaktan ziyade ayrımını yapmakta zorlanırlar., 7,8

\section{Temporomandibular eklem}

Temporomandibular eklem (TME) karmaşık sinoviyal bir eklemdir, menteşe hareketinin yanı sıra kayma hareketi de yapar. Yoğun fibröz, konnektif doku yapısında disk adı verilen menisküsü vardır. Temporal ve artiküler eklem yüzeyleri diğer eklemlerden farklı olarak hiyalin kartilaj yerine, fibrokartilajla örtülmüştür. ${ }^{11}$

Osteoartrite bağlı oluşan değişiklikler dışında TME'de yaşlanmaya bağlı olarak değişen fonksiyonlara adaptasyon için eklem ve disk yüzeyinde remodelasyonlarla bazı yapısal ve fonksiyonel değişiklikler gözlenir. Temporal kemikte, glenoid çukurun derinleşmesi veya artiküler çıkıntının düzleşmesi gibi olaylar, dejeneratif olabileceği gibi daha çok adaptif değişikliklere bağlı olarak meydana gelir. İlerleyen yaşla birlikte artiküler disk incelir, eklem yüzeylerinde düzleşme ve nodüler tarzda kalsifikasyonlara sık rastlanır. Eklemi yağlayan ve koruyan sinoviyal sıvı yaşlanmayla azalır. Bazen disk öne yer değiştirir, arkasındaki dokularda hücrelerin sayısı ve damarlanma azalır. Bazı vakalarda diskin yer değiştirmesi diskin posteriorunun perforasyonuyla sonuçlanır. .,7,11,14 $^{2}$

Dişsiz yaşlı hastaların yarısından fazlasında ve dişleri olan yaşılıarın üçte birinde TME hastalıklarının semptom ve bulguları mevcuttur. Bununla birlikte yaşlı bireylerde gençlerden daha fazla oranda TME hastalıklarıyla ilgili semptomlar vardır. ${ }^{14}$

\section{SONUÇ}

Yaşlanmayla birlikte ağız ve ağız çevresindeki dokularda meydana gelen fonksiyonel ve yapısal değişiklikler, yaşamları boyunca bireylerin tüm vücutlarında ortaya çıkan değişiklikleri yansıtır. Bazı fizyolojik değişiklikler yaşlanma sürecinin ayrılmaz bir parçası gibi görünmekle beraber bu değişiklikler, özellikle dişlerde ağrıyı tetikleyen ya da yaşlı bireylerin yaşam kalitesi üzerinde olumsuz etki oluşturan patolojik değişikliklerden dikkatli bir şekilde ayırt edilmelidir. Yaşlanmayla oluşan değişikliklerle hastalık durumunda görülen değişiklikler arasındaki fark her zaman net değildir. Bu ayrımı yapmak kişinin fizyolojik durumu ve genel sağlık durumunun belirlediği rezerv gibi birçok faktöre bağlıdır. Diş hekimi bu değişikliklerin farkında olmalı ve tanı koymada, tedavinin planlanması ile uygulamasında gerekli modifikasyonları yapabilecek bilinçte olmalıdır. Mevcut yaşılıarın ve yaşlanmakta olan nüfusun değişen intiyaçlarına göre önleyici ve koruyucu önlemler almalıdır. 


\section{KAYNAKLAR}

1. Beğer $T$, Yavuzer $H$. Yasslılık ve Yaslıllık Epidemiyolojisi. Klinik Gelişim. 2012; 25: 1-3.

2. Nigam Y, Knight J, Bhattacharya S, Bayer A. Physiological changes associated with aging and immobility. J Aging Res. 2012; 2012: 468469.

3. Nazlıel HÇ. Yaşlıda Ağız ve Diş Sağlığı. Turkish Journal of Geriatrics. 1999: 2(1); 14-21.

4. Uzun H, Nazlıel HÇ. Yaşlıda Medikal ve Dental Hikâye ile Ekstraoral, Intraoral ve Dental Muayene Bulguları. Turkish Journal of Geriatrics 2000; 3(1): 15-21.

5. Fehrenbach MJ. Aging of Oral Mucosa: Correlating underlying changes with clinical patient needs. Academy of Dental Therapeutics and Stomatology. A Peer-Reviewed Publication. 2015. Available at: https://www.dentalacademyofce.com/courses/2801 \%2FPDF\%2F1503cei_Fehrenbach_WEB.pdf.

6. Razak PA, Richard KM, Thankachan RP, Hafiz KA, Kumar KN, Sameer KM. Geriatric Oral Health: A Review Article. J Int Oral Health 2014;6(6):110-6.

7. Mckenna G, Burke FM. Age-related oral changes. Dent Update. 2010; 37(8): 519-23.

8. Saunders MJ, Yhe CK. Oral health in elderly people. In: Geriatric Nutrition. Chernoff R, ed. 4th ed. Burlington, MA: Jones \& Bartlett Learning; 2014: 165210.

9. Carvalho TS, Lussi A. Age-related morphological, histological and functional changes in teeth. J Oral Rehabil 2017; 44(4): 291-298. doi: 10.1111/ joor.12474.

10. Murray PE, Stanley HR, Matthews JB, Sloan AJ, Smith AJ. Age-related odontometric changes of human teeth. Oral Surg Oral Med Oral Pathol Oral Radiol Endod 2002; 93: 474-482.

11. Nazlıel HÇ, Hersek N, Özbek M. Ağız Dokuları ve Sık Görülen Ağız ve Diş Sorunları. İçinde: Temel Geriatri. Gökçe-Kutsal Y, Aslan D, Editörler, 1. Baskı. Ankara: Öncü Basımevi; 2007:329-348.

12. Russel SL, Ship JA. Normal Oral Mucosal, Dental, Periodontal and Alveolar Bone Changes Associated with Aging. In: Improving Oral Health for the Elderly An Interdisciplinary Approach. Lamster IB, Northridge ME, Editors, 1th Edition, New York: Springer, 2008: 233-46.

13. Erinç Ö, Zuhal ET. Yaşlanmanın Çiğneme Sistemine Etkileri. İstanbul Üniversitesi Diş Hekimliği Fakültesi Dergisi 2012; 46(2): 58-65.

14. Hıltunen K. Temporomandibuler disorders in elderly "A 5-year follow-up of signs and symptoms of TMD". University of Helsinki, Faculty of Medicine, Institute of Dentistry. (Doctoral Thesis) 2004: 1-55.

15. Fried K. Changes in pulpal nerves with aging. Proc Finn Dent Soc 1992;88 Suppl 1: 517-28.
16. Needleman I. Aging and the Periodontium. In: Caranza's Clinical Periodontology. Newman M.G, Takei H.H, Carranza F.A. Editors, Night Edition; Philadelphia: Saunders, 2002: 245-52.

17. Heath R, Goldspink G. Aging changes in human muscle and bone in relation to oral function and general health. Gerodontology 1998;15(1): 1-2.

18. Bhaskar A, Chandra A, Singh SV, Agarwal S. Effect of age on oral tissues. International Journal of Dental Sciences and Research (IJDSR). 2011; 29 (3): 110-2.

19.Al-Drees A. Oral And Perioral Physiological Changes With Aging. Pakistan Oral \& Dental Journal. 2010; 30(1): 26-30.

20.Desai S, Upadhyay M, Nanda R. Dynamic smile analysis: changes with age. Am J Orthod Dentofacial Orthop. 2009; 136(3): 310-11.

21.Penna V, Stark GB, Eisenhardt SU, Bannasch $\mathrm{H}$, Iblher $\mathrm{N}$. The aging lip: a comparative histological analysis of age- related changes in the upper lip complex. Plast Reconstr Surg. 2009 Aug;124(2): 624-28. DOI: 10.1097/ PRS.0b013e3181addc06.

22. Wohlert AB. Tactile perception of spatial stimuli on the lip surface by young and older adults. $J$ Speech Hear Res 1996 Dec; 39(6): 1191-98.

23.Amir C, Catovic A, Komar D. Aging Trends and Impact on Dental Practise. International Journal of Prosthodontics and Restorative Dentistry (IJOPRD) 2011; 1(2): 101-4.

24. Galo R, Vitti M, Santos CM, Hallak JEC, Regalo $\mathrm{SCH}$. (2006): The effect of age on the function of masticatory system- an electromyographical analysis. Gerodontology 2006; 23: 177-82. Doi: 10.1111/j.1741-2358.2006.00113.x.

25. Pontefract HA. Erosive toothwear in the elderly population. Gerodontology 2002:19(1); 5-16. https://doi.org/10.1111/j.17412358.2002.00005.x.

26. Ogawa, T, Annear M J, Ikebe K, Maeda Y. Taste-related sensations in old age. J Oral Rehabil 2017: 44; 626-35. doi:10.1111/ joor.12502.

27.Feng $P$, Huang $L$, Wang $H$. Taste bud homeostasis in health, disease, and aging. Chem Senses 2014; 39(1):3 -16. doi: 10.1093/ chemse/bjt059.

28. Uota M, Ogawa T, Ikebe K, Arai Y, Kamide K, Gondo Y, Masui Y, Ishizaki T, Inomata C, Takeshita $\mathrm{H}$, Mihara $\mathrm{Y}$, Maeda $\mathrm{Y}$. Factors related to taste sensitivity in elderly: cross-sectional findings from SONIC study. J Oral Rehabil 2016; 43: 943-952. doi:10.1111/ joor.12442. 
29. Ogawa T, Uota M, Ikebe K, Arai Y, Kamide K, Gondo $\mathrm{Y}$, Masui $\mathrm{Y}$, Ishizaki $\mathrm{T}$, Inomata $\mathrm{C}$, Takeshita $\mathrm{H}$, Mihara Y, Hatta K, Maeda Y. Longitudinal study of factors affecting taste sense decline in old-old individuals. J Oral Rehabil 2017;44: 22-9. doi: 10.1111/joor.12454.

30.Ghaffari T, Hamedi Rad F, Mosadeg Kahnamoee S. Evaluation of the Effect of Upper Complete Denture on Gustatory and Olfactory Senses. Journal of Dental Research, Dental Clinics, Dental Prospects 2009; 3(4): 132-5. doi:10.5681/joddd.2009.032.

Yazışma Adresi:

Esin BOZDEMIR

Süleyman Demirel Üniversitesi

Diş Hekimliği Fakültesi

Ağız, Diş ve Çene Radyolojisi AD, Isparta

Tel : : +90 5363287747

E-mail :dtesin@hotmail.com 